\title{
Christianity in Early Kenyan Novels: Ngugi Wa Thiong'o's Weep Not, Child and The River Between ${ }^{1}$
}

\section{Godwin Siundu \& Busolo Wegesa}

\begin{abstract}
A dominant feature in the novels of Ngugi Wa Thiong'o is the way he presents Christians and Christianity, at best as indifferent to the plight of the majority of the people, and at worst as accomplices in institutionalized exploitation, humiliation and dehumanization of the greater majority. Parts of the explanation for Ngugi's impatience with Christianity lie, perhaps equally, in his childhood experiences as a colonial subject who was coerced into recognizing Christianity as equivalent to Western civilization, as well as his later encounter with Marxist thought that associated religion with the systematized economic exploitation of the majority of people. Yet as a model of spiritual organization, Christianity has no doubt played an important role in fashioning past and present individual and group identities with regard to existing structures of power, which is probably why Ngugi is unable to narrate the experiences of his people without allocating a remarkably large space to it. In light of this, we read the two novels as attempts by the writer to project the trauma caused by and the tensions of Christianity among the colonized subjects as important influences in the formation and development of (post)colonial Kenyan subjects.
\end{abstract}

Key Words: Ngugi Wa Thiong'o, Christianity, postcolonial, subjects.

\section{Introduction}

"The Bible contained the greatest sentence in English literature ...."2

This article attempts a critical reading of Christianity in colonial times as captured in the early novels from Kenya. We specifically refer to Ngugi Wa Thiong'o's Weep Not, Child (1964) and The River Between (1965), to show the author's disquiet with Christianity as a $\operatorname{cog}$ in the wheel of colonialism, and argue that both enterprises are repugnant in their tendency to dehumanize the colonized subject, albeit in different ways. We focus on Ngugi for various reasons: first that he is arguably the most celebrated Kenyan creative writer who has also widely philosophized his ideas by way of critical essays; and, secondly, that a closer reading of his texts reveals an uneasy relationship between, on the

\footnotetext{
${ }^{1}$ An earlier version of this essay was presented at the AMECEA GABA Publications / Moi University Writers' Conference held between $5^{\text {th }}-6^{\text {th }}$ May 2006 at the AMECEA GABA Pastoral Centre in Eldoret, Kenya. We are gratefully acknowledge the organizers of the conference and the participants for their comments on the earlier draft.

${ }^{2}$ Ngugi Wa Thiong'o makes this assertion in a different context. See Moving the Centre: The Struggle for Cultural Freedoms. London: James Currey, 1993. p. 33
} 
one hand, his religious and spiritual disposition and his socio-cultural and political views on the other. In a sentence, we chose Ngugi because he epitomizes to a remarkable degree the position of the writer both as a creative but also as a spiritual being. ${ }^{3}$ This position is so aptly captured by Ngugi in Homecoming (1972), when he notes:

I am a writer. Some have even called me a religious writer. I write about people: I am interested in their hidden lives; their fears and hopes, their loves and hates, and how the very tension in their hearts affects their daily contact with other men: how, in other words, the emotional stream of the man interacts with the social reality. (our emphasis, 31)

As a writer, therefore, Ngugi is not satisfied with the surface appearance of society and individuals, rather he is constantly probing deeper in order to give meaning to what is visible; and to seek answers to questions about the whole spectre of human life. This, we take, is similar to what religion seeks to achieve. Ngugi also interests us because his works have touched Kenyans of all spheres either directly, by giving narrative to their experiences, tensions and conflicts or indirectly by creating conceptual frameworks that enable them to reflect upon their circumstances, past and present, and consciously try to order the future to their best advantage.

There is little doubt that Christianity is one of the most enduring and embraced legacies of occidental incursions into African geo-spaces. As we note later in this article, the examples of Phyllis Wheatley and Bishop Ajayi Crowther amply demonstrate the power of Christianity as taught to the African by the non-African: even the worst and most unequal state of captivity through slavery could not but seduce the captives into a well articulated celebration of new religious values couched in the idioms of salvation. The physical and psychological strains of slavery and colonialism notwithstanding, the attendant Christendom allowed those inclined Africans a chance to break with their

\footnotetext{
${ }^{3}$ Ngugi is not the only writer whose works are heavily influenced by, or draw on Christian teachings. Indeed the early African American writings, such the poetry of Phyllis Wheatley - who wrote as far back as 1773 - were more inclined to the positive attributes of Christianity. The same is true of other writers coming after her in the United States as in the broader African Diaspora: James Baldwin, Richard Wright, George Lamming, among others. Equally significant is the fact that among the earliest writers in continental Africa were some who embraced Christianity and its values.
} 
"shameful" pasts of cannibalism, superstition and idolatry; or simply, with all that was consistent with their status as backward human beings in dire and urgent need for refinement by the logic of colonization and conversion. It was convenient for the dominating whites that the dominated blacks focused more on this new form of salvation and less on their cultural, economic and political subjugation made possible by the colonial structures.

It would come as little surprising hence that some of the earlier converts were completely tormented by the guilt of their "sinful" pasts and decided to atone for their personal histories by distancing themselves from their unconverted kith and kin who reminded them of everything that they wished to forget. These characters did live in a perpetual state of panic and fear of the remote possibility of backsliding; living confused lives of mental turmoil due to many and complex questions regarding their identities at personal and communal levels on the one hand and, on the other, the utopia of endless paradise promised in the bible. It is this drama that dominates Ngugi Wa Thiong'o's early writings as he captures that wide array of experiences that besieged our forbearers who bore the full weight of classical colonialism. Their lives, documented extensively in other texts as well, are re-cast in these novels in the way the world views were constituted in such simplistic polarities that in actual fact belied realities much more complex than Christian/pagan, holy/sinful, etc.

For purposes of anchoring of our paper here, we isolate one of those dialectics of faith and superstition presented in Ngugi's novels as distant shades of religion and spirituality. We intend to show that a), the varied ways in which Christianity/Colonialism and the Africans' response/resistance to it in the Kenyan situation generated narratives of approval and condemnation depending mainly on the positions of the same commentators, and b), that over time, these narratives have shown the romance of religion and literature as inextricable bedfellows, the essence of which is partly reflected in Ngugi's assertion that forms our epigraph. 
If Christianity appears as a controversial issue in Ngugi's early writings, this controversy is mooted and sustained by the author's consistent polarization of his influential characters along the lines of opposition to, or support for, the new religion. At the base of this characterization is the author's guiding philosophy that is simply geared towards dramatizing the land question as the paramount concern during the colonial era, as well as the varied responses that this scenario invited. The conflict is further heightened by the presence in the middle ground of many people who are not overtly clear regarding which side of the divide to ally themselves to, which people form the primary target of the two idioms of salvation - either from the sins of paganism and its attendant vagaries as preached by the missionaries, or from external adulteration a tried and tested cultural heritage as asserted by traditionalists.

We begin our discussion by focusing on the Gikuyu who "resisted" Christianity in our chosen novels, and later on look at the way this Christianity was presented and defended by the early missionaries and their Gikuyu converts. Although it may appear logical to start with the missionary work before moving on to the responses such work elicited, we have disregarded this simple linearization of religious change for good reasons. Importantly, the historical introduction of Christianity to Kenya as indeed to Africa did not find a spiritual/religious vacuum; hence the need to start by acknowledging the initial structures of faith if only to avoid insinuations of religious emptiness prior to the coming of missionaries. This sub-division is only meant to clarify our arguments by sustaining a conversation within our paper, and will not stop us from mentioning various characters from different camps if it helps us achieve the desired clarity. 


\section{The Colonized, their Culture and the Paradoxes of Christianity}

Ngugi's first novel The River Between is set in the turbulent era of transition from the traditional society of the Gikuyu people to one infiltrated by the western ways. It deals therefore with the challenges the society faces as it struggles to resist this conquest by the marauding force that may lead to disintegration, and at the same time examines the choices and dilemmas faced by the key individuals in the situation. In The River Between, both Christianity and traditional Gikuyu cultural values are presented as diametrically opposed to each other, where characters have to choose adherence to one on an "either / or" basis. These characters are led by Reverend Livingstone and Joshua for the Christians, and Kabonyi - himself a former convert - on the part of Gikuyu conservatists / traditionalists. It is quite significant that this choice is not flung at the characters without notice: many of them have ample time to reflect upon their views as personified by the luminaries from both sides of the spiritual / religious divide. The "grace period" is given through the slow introduction of the conflict and, in the case of the Gikuyu beliefs, an excavation of the myths of origin for the entire community and its history. As early as this point, the Gikuyu tradition presented by Ngugi intersects with Christian teachings to the extent that they each employ myth to explain, in their separate ways, origins of their people. Particularly important and common in the two explanations is the way in which the people who originate are given land, both a cause for and a surface for the impending conflict in the novel.

The introduction of the geography of the physical setting in some ways alludes to the original Garden of Eden as captured in the book of Genesis in the bible, but it also points out the way in which colonial regimes mapped or otherwise appropriated geographical spaces in order to configure their desired subjects. Harry Garuba (2002) argues that "[c]olonial mapping represented landscapes of mobility for the coloniser, but for the colonised it presented a circumscribed landscape of constraint." (96) This colonial mapping, Garuba proceeds, was essential because "maps became instruments for the production of colonial and postcolonial subjectivities by constituting and constraining what should be enunciated within their discursive space."(90) As a reading of Ngugi's The River Between reveals, the division of the Gikuyu community by River Honia is 
hijacked by the existing colonial and Christian missionary regimes to construct Gikuyu subjects along the dichotomies of believers, saved and therefore 'good' Gikuyus opposed to the superstitious, doomed and therefore 'bad' Gikuyus. It is the undying optimism in Ngugi and the long-held bonds of a shared Gikuyu spirituality that sees this divide bridged by an increasing understanding of the divisive interests of the colonial, Christian masters. In laying the background for the approaching disintegration of society, Ngugi describes the two regions inhabited by the inhabitants thus: "Kameno and Makuyu were no longer antagonistic. They had merged into one area of beautiful land, which is what, perhaps, they were meant to be. Makuyu, Kameno and other ridges lay in peace [...] as one stood on the hill of God" (TRB, 16, our emphasis). Later, the mountain with spiritual significance in the Gikuyu myth of Mugo Wa Kibiru's prophecy is described as "of Hewho-shines-in Holiness" (17), clearly invoking the idiom of purity and immortality as captured in the capitalization of " $h$." This presentation of the physical setting as pristine and inhabited by a supernatural being is, in our view, a deliberate attempt by Ngugi to bridge the gap between the traditional Gikuyu mythology and the advancing - within the text - Christian teachings. It is also significant that both forces couch their positions in the rhetoric of salvation: whereas the traditionalists speak of salvation of the community from infiltration of the adulterating influences of the white man and Chiristianity, the latter are concerned with the salvation of the Gikuyu people from that barbarity of superstitious ways of life. For both camps, the image of blood and prophecies of redemption punctuate as they justify their continued concern for the future of the people they live with. Whereas the camp of Reverend Livingstone is propelled by the biblical story of Jesus - the Son's - sojourn on earth and the salvation that belongs to all who believe in and follow his teachings, the traditionalists on the other hand draw inspiration from an ancient Gikuyu myth that promises a form of salvation for the Gikuyu people. Chege, the last in the line of Gikuyu seers, reveals the prophecy to Waiyaki his son: "Salvation shall come from the hills. From the blood that flows in me, I say from the same tree, a son shall rise. And his duty shall be to lead and save the people." ${ }^{4}$ (20, our

\footnotetext{
${ }^{4}$ Ngugi's reference to "the hills" here is an allusion to Gikuyu myth of spiritual origin in the Mt. Kenya region. Over time Mt. Kenya has simultaneously, and sometimes alternately, occupied the fluid position of political, religious and spiritual nerve centre for invoking Gikuyu nationalism. The most celebrated reference to Mount Kenya is seen in Jomo Kenyatta's Facing Mount Kenya (1938).
} 
emphasis) Hence, the idiom of salvation, the image of blood and agency of a chosen son cut across Christianity and Gikuyu mythology, which parallels Jesus' injunction in the Bible that "I am the way, the truth, and the life. No one comes to the father except through Me." (John 14:6)

Chege's revelations to his son concerning the community's secrets are ironically preparatory of Waiyaki's later encounter with Christendom at Siriana under the tutelage of Reverend Livingstone. Waiyaki's dilemma begins this early when the old Gikuyu order (represented by Chege his father) and the spreading Christianity both see in him a potential savior for the people. Waiyaki's predicament is the same as Njoroge's, the protagonist in Weep Not, Child, both who see the white man's education and its attendant Christian teachings as important rites of passage in their quest to save their people. In Weep Not, Child, Njoroge's "belief in a future for his family and the village rested then not on a hope for sound education but also on a belief in a God of love and mercy, who long ago walked on this earth with Gikuyu and Mumbi, or Adam and Eve." (55) Clearly, Njoroge's and Waiyaki's attempt at appropriating the positives in the white man's teachings capture the symbiotic relationship between the existent Gikuyu myths and the emerging Christian influences such that the Mumbi versus Adam and Eve myths enjoyed some form of mutual validation of each other, just as the leaders in the different camps of Christendom and traditionalists drew additional authority from each other because they were the elites in their respective constituencies. In retrospect, it is now clearer. The early Christian missionaries knew that the success of their missions depended in large measure on the creation of local educated classes - who would be subtly, if paradoxically, encouraged through persecution to rebuff Christian teachings like Njoroge and Waiyaki and then be used as examples of ungrateful Africans who benefited from Western Enlightenment only to turn against the very missionaries and their teachings. This strategy was used to whip the collective guilt of Africans into submission of both Christianity and colonialism. By casting Njoroge and Waiyaki in messianic roles, Ngugi keeps pace with the trends of the early to mid $20^{\text {th }}$ Century among continental Africans and those in the Diaspora. In a somewhat different context, Dan Ojwang (2004) observes that "[i]n the twentieth century, black leaders both in Africa and the Diaspora were often 
cast in the mould of biblical figures such as Moses of the Messiah..." (44) It is important that this recasting was uppermost in Ngugi's mind that initially he contemplated entitling the novel The Black Messiah. What is significant regarding Waiyaki's role is that the idea of salvation associated with him captures the different meanings that various characters attach to it: for the likes of Chege and other conservatives, it means the day the white man and his Christian religious influences will be expelled from the ridges, while for the converted like Joshua, it is about abandoning the pagan ways and seeking protection from the Christians' God, here represented by Reverend Livingstone.

The western onslaught against Gikuyu paganism is led by Reverend Livingstone who has established a mission at Siriana for the purposes of training Africans in Christian doctrine and future leadership roles. He is supported in his mission by enthusiastic converts like Joshua, appropriately named after the Biblical leader who took over after Moses death and led the Israelites in the final lap to the Promised Land away from the slavery of Egypt and who, in the context of the novel, should lead fellow Gikuyu people from the slavery of sin. As his name suggests, Reverend Livingstone's opinion of Africans is cast in stone; he treats them as children who need guidance from the whites. One must be firm with them lest they go astray! His mission of evangelism is a war against "the barbarity of Gikuyu customs" ... "entrenched in their blind customs." (55) He has found the Gikuyu people "immoral through and through" (56) and worshippers at the throne of the "Prince of Darkness". (56) Reverend Livingstone is intolerant and vengeful, preaching a message of racial hate by the choice of a position of superiority over other human beings. Sadly, people like the Reverend Livingstone are a part of the history of the early Christian church in Kenya and even more unfortunately, it is they and their racist vision that remain unforgettable because of their efforts to have their earlier converts to obliterate their African past. Admittedly, Reverend Livingstone does not represent all, or even the best, of pioneer Christian evangelists in Mount Kenya and the outlying regions; rather he captures the unfortunate reality of the earlier conflation of the Christian church and the state in Kenya as in other colonies. Writing on the relationship between the church and state politics in a different context, Henry Okullu asserts that "[t]here have been those who believe that Church and State are mere sides of the same coin, and that 
church leaders are officials of the State. This view is usually called Erastianism and was strongly held by leading reformers like Luther, Zwingli and Calvin."5 It is not helpful for our purposes to implicate the likes of Reverend Livingstone in the theoretical complexities of Erastianism, given as it is that its very popularity was not in Africa. But it explains the practice of Reverend Livingstone and others who invoked the vocabulary of spiritual/moral reformation as their guiding philosophy whenever they had Africans in mind. It also explains Ngugi Wa Thiong'o's view on earlier missionaries as the sentries of imperialism and its attendant acts of material and cultural dispossession of the native Kenyans that they came in earlier contact with. "Take Siriana mission for example, the men of God came peacefully. They were given a place. Now see what has happened. They have invited their brothers to come and take all the land." (64) As we show later in this article, it is this same view that Ngugi emphasizes in Homecoming, and which, as Valentine Mudimbe has argued in his seminal The Invention of Africa (1988: 51). Accordingly, the pioneer missionary language is characterized by a vocabulary of derision (dismissing other groups and their values as pagans), refutation (or reduction of systems of non-Christians to blackness and backwardness) and demonstration (of God's truth in an authoritative way of converting the non-Christians. Ultimately, Mudimbe argues that this position of the missionaries is more of a cultural than religious position, and thereby implies that a rejection of the orthodoxies of Christianity in such a context does not necessarily amount to a rejection of a religious or spiritual model, but a cultural and political one.

Hence, if Ngugi's presentation of Christianity in his earlier novels is ambivalent - at once acknowledging its capacity to influence a people's thought patterns even as he mocks its rigidities - we note that his is not a rejection of Christianity in toto, but a reservation about Christian demagoguery that presents Western "civilization" through classical colonialism and Christian salvation as one. ${ }^{6}$ This explains in part the difficulties that

\footnotetext{
${ }^{5}$ See Church and Politics in East Africa. Uzima Press, Nairobi. 1974, p. 15.

${ }^{6}$ Admittedly, Ngugi in his later writings developed a more hardline stance towards Christianity in general and its teachings. After buying into the Marxist ideologies, Ngugi saw Christianity as another avenue of creating elitism that served to impoverish more than enrich the majority of people and which, like classical colonialism, only camouflaged imperialism. In Detained: A Prison Writer's Diary, Ngugi asserts that "the colonial governors, settler-chiefs and soldiers [...] were honest [...] impatient, and rightly so, with the more
} 
these earlier missionaries and their converts faced in spreading the word. There was a degree of cross-purpose communication in the sense that while such missionaries as Reverend Livingstone viewed a majority of Africans as resisting the word of God, the people were in fact apprehensive of the colonialist appendage to the word, a problem that was compounded by the human instinct to mistrust the unknown. Even among African leaders some were sympathetic to such forms of resistance and knew that there was some value in the ways of the white people. In The River Between, this realization is summarized thus: "[f]or Waiyaki knew that not all the ways of the white man were bad. Even his religion was not essentially bad. Some good, some truth shone through it. But the religion, the faith, needed washing." (141, our emphasis) This realization on the part of Waiyaki is particularly significant because it captures, to a degree, the author's attempt to present a fair picture of the antagonistic forces at play: while Western Christianity may not be essentially bad as a religion, traditional Gikuyu beliefs are not ideal either. This suggestion for a compromise then captures the true place of religion / spirituality in human life; the need to accommodate differences in perception without necessarily degenerating to dismissals. This is, perhaps, the point in G.D Killam's earlier reading of Ngugi's early novels, where "the author establishes a metaphoric framework for the first novel [The River Between] in which he traces the correspondence between the Kikuyu and Christian creation myths which see Mumbi on the one hand, and Adam and Eve on the other, as founding figures." (129) It is because of this that the novel also has characters like Waiyaki and Muthoni who try to straddle - though unsuccessfully - the two worlds of Christian beliefs and traditional values. We aver that the failure of Waiyaki, Muthoni and Nyambura to successfully harmonize Christian beliefs and traditional Gikuyu values does not signal the irreconcilability of the two. This point is better understood if we read the novel within its historical setting - a time when to attempt any compromises was to invite charges of betrayal. Essentially, Ngugi's presentation of harmonization as seen in the efforts of these characters is that of a good, if a tad premature, idea.

deceitful methods of the missionaries and administrators who were trying to educate Kenyans into accepting the same thing: submission." (44) 
Indeed, these characters that appear to straddle two worlds are also the most memorable. They represent a more meaningful and humanistic search for spirituality. Muthoni's efforts are particularly remarkable. As Joshua's daughter, she is a Christian by birth and choice: "I say I am a Christian and my father and mother have followed the new faith. I have not run away from that. But I also want to be initiated into the ways of the tribe." (43, our emphasis) Muthoni, in the highlighted remarks, affirms an understanding that "the new faith" and "ways of the tribe" are not mutually exclusive. Further, Muthoni is conscious that religion which is not rooted in the cosmic reality that she inhabits is incomplete by itself, and so she runs away from home to be circumcised, thus making herself an outcast from home. She sacrifices a relatively comfortable life in order to satisfy a spiritual yearning that captures the bigger dilemma of people whose entrenchment in one belief system only makes them more acutely aware of the deficiencies of adopting a unilinear approach to life. Muthoni's dilemma captures a key link between belief in traditional societal values and the emerging Christian teachings: that of reflections on their necessity in the cultural and psycho-social utility. To that extent, Muthoni cuts a Christ-like image in a desire to embrace a Christianity that takes cognizance of her place in her society. The tribe, to which all her agemates owe their allegiance, is the social fabric that determines roles and relationships in this landscape. Indeed Muthoni's plight captures the bigger sense of alienation that earlier Christian converts in Africa suffered at the hands of their fellow kinsmen. Ample examples of the problems such early converts went through can also be found in Chinua Achebe's early writings. For instance Okonkwo, Achebe's most famous character, disowns his son Nwoye - just like Joshua disowns Muthoni: "[f]rom that day, Muthoni ceased to exist for him, in his heart" (36) - when the latter chooses to join the new church led by hitherto societal ne'er do wells. For Okonkwo, Nwoye's decision is the height of humiliation for his family, and invites nothing short of a paternal curse. The same is seen in Achebe's other novel, Arrow of God, where Oduche, the young son to the main character, is traumatized by his inability to reconcile Christian teachings and traditional Igbo values espoused by just about everybody he knows. In both novels, Christian converts invite varied responses from the traditionalists, depending on the latter's mood, from satirical laughter to open hostility. These early converts suffered double alienation in the sense 
that they had forfeited their rights to take part in the activities of their respective clans yet, by virtue of their newness in the new religions, they could never move to the pinnacles of these new churches and their affairs. For Muthoni hence, to be outside the traditional Gikuyu set is to condemn herself to isolation, loneliness and meaninglessness. Muthoni thus reads the positive and life giving elements within the traditional customs and wishes to retain them.

The act of circumcision that Muthoni undergoes can be treated at a metaphorical level. As Waiyaki observes, "[c]ircumcision of women was not important as a physical operation. It was what it did inside a person. It could not be stopped overnight... If the White man's region made you abandon a custom and then did not give you something else of equal value, you became lost." (142) Muthoni thus attempts to fuse the two elements - tradition and Christianity, selecting what she deems best from each of them. However, her choice is also tragic partly because she does not succeed in her attempt at reconciling the two major influences in her life. This, in part, is because of a degree of simple-mindedness on her part, which is why she cannot conceive of any other way of growing into womanhood other than through circumcision - "[s]urely there is no tribe that does not circumcise. Or how does a girl grow into a woman?" (26) - thereby simplifying a rather complex process. Ironically, this same naivety underlines the need for her to envision other possibilities of undergoing transition from childhood to womanhood - as Waiyaki observes in the foregoing quotation, circumcision is much bigger that the physical aspects of the ritual. Muthoni's pronouncement above indicates not just how little she knows about other people outside the Gikuyu tribe - although not of her fault - but also that her support for Gikuyu girl circumcision is based on a singular wish "to grow into a woman" in her construction of womanhood. Waiyaki and Nyambura's attempts to make her change her mind are unsuccessful, partly because of the enthusiasm of some people that often generates rigid positions. Her singular understanding of issues is not limited to her; as a fact, she shares it with her father, Joshua, "a man who, once he made up his mind, was hard to deflect from his set purpose." (27) 
Yet, the society is not ready for the radicalism she stands for and she dies young. Her last words are a valiant proclamation, “...tell Nyambura that I see Jesus. And I am a woman, beautiful in the tribe..." (53) Waiyaki, himself a child of two worlds, is left pondering over this cryptic message. ${ }^{7}$ Earlier on when she runs away from home to be circumcised Waiyaki, more even than the other people is shocked beyond comprehension. Her decision awakens the conflicting forces within him and these magnify towards a crescendo. Waiyaki's biggest challenge is whether he is capable of bridging the divide between the Christians and the converts, between Makuyu and Kameno; whether the spiritual being can be achieved without sacrifice and self-denial; whether one can readily abandon the realities of his existing cultural traditions and embrace a new ethos unquestioningly. The Gikuyu people have developed an ethos over ages and their rituals are the outward manifestations of their affirmation to the group's survival. The question then is whether religion can have any meaning if it divorces people from their total environment. As Waiyaki realizes,

[a] religion that took no count of people people's way of life, a religion that did not recognize spots of beauty and truths in their way of life, was useless. It would not satisfy. It would not be a living experience, source of life and vitality. It would only maim a man's soul, making him fanatically cling to whatever promised security, otherwise he would be lost. (141)

And that, he reasons, is Joshua's predicament: "[p]erhaps that was what was wrong with Joshua." (141) Waiyaki sees Joshua's problem as the failure to be anchored to something that was rich and firm and instead being driven by fear of the unknown. Yet, as we pointed out earlier in this paper, the new religion has its very attractive elements which even Waiyaki cannot fault. However it also has the unpleasant ones which if "washed away" would leave the universals and thus fit into people's way of life. The greatest excess baggage that the new religion possesses is its manner of propagation. Ngugi in Homecoming reminds us that the Gikuyu have developed a saying that there is no difference between the European settler/colonial administrator and the missionary priest:

\footnotetext{
${ }^{7}$ This phrase belongs to Mugo Gatheru, who published a novel by that title way back in 1964. See Child of Two Worlds, London: Routledge \& Kegan Paul Ltd.
} 
[g]utiiri muthungu na mubia. It is explained in the anecdote that we mentioned earlier in this essay on the conspiracy between the two that led to the alienation of Gikuyu land: "[t]he Mubia told the people to shut their eyes in prayer, and when later they opened their eyes, the land was taken. And then, so the story goes, the Mubia told them not to worry about those worldly things which would be eaten by moth; and they sang: [...] this world is not my home, I am only a pilgrim." (33) The combined use of violence and trickery in the spread of Christianity during the late pre- and earlier colonial epochs as re-presented in Ngugi's writings is what creates a necessity for new forms of leadership such as embodied in Ngugi's fictional Waiyaki. These new leaders are those who are sufficiently exposed the colonial-Christian teachings, but also in the oral literary heritage of the Gikuyu people who recognize him as their saviour against the new religious onslaught. In an important sense then, the new religion occasions crises of identities and belonging to such leaders, making them religious hybrids who straddle religious worldviews that stand in opposition to each other. For them, compromise comes almost naturally precisely because of the alienating distance that exists between them and the opposing spiritual orientations.

This may explain Waiyaki's conduct, whose vision is to seek reconciliation and hopefully attain a path which can entrench Christianity in his society but grounded in a Gikuyu cosmos and devoid of its western trappings. As we indicated earlier in this paper, there is a strong suggestion that he is not successful in the context of the novel, although the seed that Muthoni had planted is passed on to him and it will continue in others and hopefully come into fruition. In spite of Waiyaki's failure to reconcile the two dominant ways of reading the world in the novel, he captures quite acutely the dynamics of embrace and /or denial of the influence of the new religion. He may posture as a Gikuyu traditionalist, albeit educated in the Western sense of the word, but he is also a convert to Christian teachings that strike a chord with his personal sense of right and wrong, partly captured in his ideals and practice of reconciliation as seen in his sympathetic dealings with Muthoni and Nyambura, as in his apprehension of many of the words spoken by Kabonyi - an embodiment of Gikuyu nativism. In this regard, Waiyaki's deep-seated Christian inclination constitutes part of a subconscious identification with Christianity, which he 
may not be aware of, but that corresponds to Ngugi Wa Thiong'o's personal shock when he realized that despite his pronouncements, his nominal identity situated him within the Christian world. As Ime Ikiddeh recounts is the foreword to Homecoming, the former James was never disturbed by the religious implications of his first name, until one of the Presbyterian men in his audience reminded him that he was indeed one of them. James Ngugi then changed to Ngugi Wa Thiong'o, ${ }^{8}$ because he felt that "James" proved his concession to imperialistic indoctrination that had always been presented him and many others as Christians, and thus saved from the barbarism of paganism that was the fate of all who were not, at least, nominally Christians. Ngugi's position regarding such names as John, Mary, Isaac and so on is that they are primarily imperialistic and only secondarily - if at all - Christian.

\section{Evangelization, Salvation and the Early Converts}

In The River Between Reverend Livingstone is set to pass the mantle of church leadership to the African convertees. Initially the two next in line are Joshua and Kabonyi. Joshua has more than proven himself ready for that task. His unquestioning belief in the white man is phenomenal to the extent that he does not notice the contradictions - such as intolerance and authoritarianism - that appear obvious to his kinsmen. Joshua is driven by two main elements, first is his faith in the invincibility of the white man, "the white man is a superior being and must be adored." For him the white man can never be wrong! He refers to whites as "unerring" and therefore their perception of the Gikuyu must be believed. Out of this therefore Joshua concludes that his people (the Gikuyu) are ignorant: "[h]e realized the ignorance of his people. He felt the depth of the darkness in which they live. He saw the muddy water through which they waded unaware of the dirt and mud."(29) For Joshua then the new dispensation means the total rejection of all his

\footnotetext{
${ }^{8}$ We note here though that the fashion in name change was also a pan-Africanist gesture during the late pre- and early post-independence Africa, with the likes of Kwame Nkrumah, Jomo Kenyatta, Sekou Toure and others silencing their non-African names as a way of signaling a final return to their African roots. Mobutu Sese Seko of Zaire pursued the same by legislating it under the banner of auntheticite. Indeed these "philosopher kings" (excepting the then Zairean leader) enjoyed rapport with the intellectual elites of the time who also changed their names. Briefly, Ngugi Wa Thiong'o was neither the first nor the most important leader to let go of his Christian name.
} 
past. He feels ashamed to have been reminded of his background. Many a time he is enraged by the fact that this is the tradition that defines his earlier being.

The other element that defines him is the extraordinary fear of the punishment proclaimed in the Old Testament, which he quotes: "[ $\mathrm{t}]$ hose who refuse him are the children of darkness; these, sons and daughters of the evil one, will go to Hell; they will burn and burn for ever more, world unending. (29) This sends him trembling uncontrollably and hastens his conversion to Christianity. It is only after baptism that the fear disappears and now he is a new person, ready to proclaim the gospel to those yet saved. His faith is in part thus a result of fear, which makes him to interpret the Bible in a very literal sense. His zeal to manifest his salvation makes him very judgmental, thereby making nonsense of one of the most enduring dictums of salvation, "thou shall not judge." According to him, all those who hesitate are like Lot's wife and they will surely be turned to a rock of salt like that biblical figure. In spite of all these, Joshua is no demagogue, dimwit or opportunistic preacher. Indeed he finds admiration even among the non-converts because of his passionate and steadfast commitment to Christianity. Unfortunately it is this aspect that we must look at critically. Joshua's limited understanding of religious doctrine coupled with an unquestioning mind ultimately renders him into an insensitive person, without any feelings or any human attachment. As a result of this, he disowns any of his relatives who cling to any aspect of the old ways. When the news of Muthoni's death is brought to him he receives it without any emotion. She had died long ago to him the moment she walked out and be circumcised and thus became the child of the devil. His God is one not of love or forgiveness, but a being to whom vengeance is the foremost intent. Whereas religion should be a reconciling element, Joshua's has no room for such. The duality that he preaches is so clearly marked out that there is little chance that an act of reconciliation is possible. This is why Joshua's religion preaches fear, hate and the break-up of families because it is insensitive to the individual soul's anguish.

Ngugi caricatures these three types - the Christians, traditionalists and the liberals - and demonstrates their limited and misdirected passion in their mission of evangelism. 
Perhaps through them there is also the question of how the clergy can rise above or remain limited in their work by their own very nature as human beings. Too often their sacred mission is compromised and they end up cutting comical, and at worst embarrassing images.

\section{Conclusion}

In this paper, we aimed at reading the presentation of Christianity in Ngugi's early novels and the crises that this religion was part of. Among other things, we have demonstrated that, a), earlier Christianity's mapping of society and subsequent hierarchization of members into general dialectics of saved/unsaved, believer/pagan and so on created modes of perception/attitudes to different members of the same society, thus generating a challenge to its own spread. Another point, b), is that the serious reservations with which Christianity was met in some quarters arose mainly in the initial presentation of the same as part of the new colonial state, what Okullu calls Erastianism. Indeed Christianity's role in persuading people to embrace colonial ideologies of difference remains a stain that soils its otherwise desirable and definitely positive influence on contemporary society's continued interaction with their spiritual world. The simple fact that, even without statistics, a majority of Kenyans are Christians attests to the presence of some potency in Christian teachings that bears meaning to many of its adherents. This is quite apart from the many welfare institutions that Christianity has sponsored and overseen in the countries perpetual constitution of communities. Yet, our acknowledgement of the church's role in building positive attributes of society can only be rendered honest if we take stock of those earlier errors of judgment committed by the likes of Reverend Livingstone and Joshua in overwhelmingly condemning as sinners all those who harbored divergent views on spirituality. Indeed such errors were not exclusively committed by those who advocated for Christianity; even among those who resisted it were those who also made human mistakes of omitting or otherwise overlooking some of the positives of Christianity. Our submission is that such errors can be explained as having arisen because of the fact of colonialism, which heightened people's worries over daily existence, its promises and threats. Essentially, they were errors committed by people who were ill-prepared to handle the change that was taking place at the time. 
All these, in part or whole form the key concerns of Ngugi Wa Thiong'o in his early writing. Ngugi in these novels shows that through literary works the ideas of Christendom may be tested by the realities of life and thus a questioning of its sustainability. In the two novels that we read for this paper, we observe that Ngugi does not just narrate a story. He creates characters who symbolize the very fabric on which society is built through a process that involves spiritual modeling such as Christianity may allow. And through these characters he goes below the surface to draw on the underlying human concerns, illustrating that though spiritual wellbeing may be an important component of human desires and survival, it makes more sense if it works in tandem with other material and physical concerns. Ngugi also demonstrates that in a dynamic situation people are often caught up in a complex pattern of wants to which they often respond in very varied ways depending largely on their priorities of the moment. Individuals undergo these reactions as they struggle within themselves to establish meaning in their life as independent entities but also against external forces that seek to disrupt the social structures that they are inextricably part of and that guarantee the continuation of humanity. Put differently, the concerns of literature thus far seem to intersect with those of religion, calling for the necessity for us to examine even further how the two areas are essential to each other.

We suggest that cutting across both disciplines is the human quest for fulfilling identities and modes of identifications. Religious identities that are celebrated by Joshua and the Reverend Livingstone are diametrically opposed to the ethnic identities that are espoused by Kabonyi and others. Middle ground attempts by Waiyaki and Muthoni reflect the pulland-push dilemmas that torment all those who find balanced meaning in diverse thought patterns represented by both forces of Christianity and tradition. Back to Christianity's mappings, the cases of these luminaries suggest that the incursion of Christendom further creates horizontal and vertical differentiation among members of the communities, thereby fitting well in the secular structures. Centres of power clearly emerge and seek to rally supporters in responding to various challenges that arise out of a people's survival desires / instincts. Such desires are usually couched in beliefs / superstitions that are 
received across generations, and are expressed as being in the very best interests of those who subscribe to them. If religion in its widest sense seeks to provide assurance for human beings in their encounter with the known and unknown, literature seeks to reflect such encounters in their various ways across time and space.

\section{References}

Achebe, Chinua. Things Fall Apart. London: Heinemann, 1958. . Arrow of God. London: Heinemann, 1964.

Garuba, Harry. "Mapping the Land/ Body/ Subject: Colonial and Postcolonial Geographies in African Narrative." Alternation 9.1 (2002): 87 - 116.

Gikandi, Simon. Ngugi Wa Thiong’o. Cambridge: Cambridge University Press, 2000.

Kenyatta, Jomo. Facing Mount Kenya. London: Secker \& Warburg, 1938.

Killam, G. D. "Ngugi Wa Thiong'o" in The Writing of East and Central Africa. G.D Killam (ed.) Nairobi: H. E. B, 1984. pp. 123 - 143.

Mudimbe, Valentine Y. The Invention of Africa: Gnosis, Philosophy, and the Order of Knowledge. Bloomington \& Indianapolis: Indiana University Press, 1988.

Ngugi Wa Thiong'o. Weep Not, Child. London: HEB, 1964. . The River Between. London: HEB, 1965. . Homecoming: Essays on African and Caribbean Literature and Politics. Westport, CT: Lawrence and Hill, 1972. Detained: A Writer's Prison Diary. London: HEB, 1981.

Ojwang', Dan. "Writing Migrancy and Ethnicity: The Politics of Identity in East African Indian Literature.” PhD Thesis, University of the Witwatersrand, Johannesburg. 2004.

Okullu, Henry. Church and Politics in East Africa Nairobi: Uzima Press, 1974. 